\title{
New palynological data on the age of the Kiltorcan Flora of Co. Kilkenny, Ireland
}

\author{
EDWARD JARVIS \\ Department of Geology, University College Cork. Ireland.
}

\begin{abstract}
The age of the fossil flora found in the Kiltorcan Formation of Co. Kilkenny has been disputed for many years, with no datable miospore assemblage ever being extracted from the plant beds due to the preservation. New exposure on Kiltorcan Hill, and experimentation with palynological techniques has allowed the extraction of two miospore assemblages. The palynological data studied shows that the strata on Kiltorcan Hill straddles the Devonian/Carboniferous Boundary; A Devonian LE Miospore Biozone assemblage has been examined from a plant bed with Cyclostigma kiltorkense whilst a Carboniferous VI Miospore Biozone date was determined for a plant bed with Lepidodendropsis sp., and? Rhacophyton. The topmost occurrence of Cyclostigma kiltorkense is unknown but it is certainly very near to the Devonian/Carboniferous Boundary. The use of Cyclostigma kiltorkense as an index fossil for the uppermost Devonian is therefore not precluded.
\end{abstract}

\section{GEOGRAPHICAL LOCATION OF EXPOSURE}

Exposure at the classic Kiltorcan localities in County Kilkenny is limited to a few small quarries on Kiltorcan Hill (Fig. 1). The Old Plant Quarry (the "Classic Quarry" of Colthurst 1978) measures only $20 \mathrm{~m}$ by $6 \mathrm{~m}$ at maximum and is situated towards the top of Kiltorcan Hill, approximately $1.5 \mathrm{~km}$ ESE of Ballyhale village which lies on the main Waterford-Thomastown road, County Kilkenny. A wealth of work has been undertaken on the palaeontology of this locality which is now unfortunately almost entirely fllled in. More extensive exposure now occurs $150 \mathrm{~m}$ to the north of the Old Plant Quarry in a network of disused Roadstone quarries, worked in the 1960's and 1970's. These cover a large area at the summit of Kiltorcan Hill (the "Council Quarry" of Colthurst 1978) and expose a seven to nine metre section of green and red siltstones and mudstones and yellow sandstones. A more recent exposure is to be found 100 metres to the south west of the Roadstone quarries. This has been termed the Kiltorcan New Quarry and was quarried during 1984-1985 where another short stratigraphic interval was exposed. This sequence underlies the Roadstone quarries and the two can be related by a section of intermittent exposure along a track (Fig.l).

\section{PREVIOUS WORK ON AREA}

Most interest in this area was originally concerned with the well preserved examples of plant fossils collected in the mid 19th Century from a small quarry on Kiltorcan Hill (the "Old Plant Quarry"). The first published work on the Kiltorcan locality was that of Forbes (1853); He described the 1851 discovery of the quarry, which was seen to "abound in fossils of great beauty and apparently entirely new". The fossil fauna includes, Archanodon jukesii (Forbes) Howse (a freshwater bivalve), Groenlandaspis disjectus (Woodward) Ritchie (fish plates) and the arthropods Belinurus and eurypterids (Clayton et al 1980). More detailed work on the flora was carried out by Chaloner, who (in Holland 1981) lists a floral assemblage including Archaeopteris hibernica (Forbes) Dawson, Cyclostigma kiltorkense Haughton, Ginkophyllum kiltorkense Johnson,Sphenopteris hookeri Baily and the seed Spermolithus devonicus Johnson. The fossil flora is very well preserved in chlorite and attracted much attention from palaeobotanists of the time [Baily $(1861,1869)$, Griffith and Brongniart (1857, $1858)$ and Haughton $(1855,1859)$. Much argument ensued as to the age of the flora. Griffith (op. cit), Haughton (op. cit), and others regarded the deposits as Lower Carboniferous, Forbes concluded a Devonian age, whilst Brongniart found the specimens were not sufficiently distinctive to enable him to decide between the two views.

No good miospore assemblage has ever been extracted from the strata on Kiltorcan Hill prior to the present study as the chlorite preservation of plant material does not aid the extraction of miospores with standard palynological techniques. Johnson (1913b) claims he observed miospores in material from the Old Plant Quarry. He experimented with some sporangia, treating them with schulze solution and ammonia, and obtained "many rounded bodies, some with triradiate mark" and concluded they were miospores. Chaloner (1968) was, however, unconvinced by Johnson's miospores. He stated that " none of his (Johnson's) preparations appear to have been preserved, and his photograph is rather unconvincing," and concluded that "that the body Johnson observed and regarded as a microspore was either an artifact of preparation or a contaminant". Chaloner (op.cit) examined megaspores on the surfaces of the sporangia of Cyclostigma kiltorkense concluding that mey were similar to the dispersed genera Lagnicula and Lagenoisporites. Yet he was unable to extract any miospore assemblages to indicate the the exact biostratigraphic level of the beds. A re-excavation of the Old Plant Quarry was made in the 1970's, Chaloner et al (1977) 


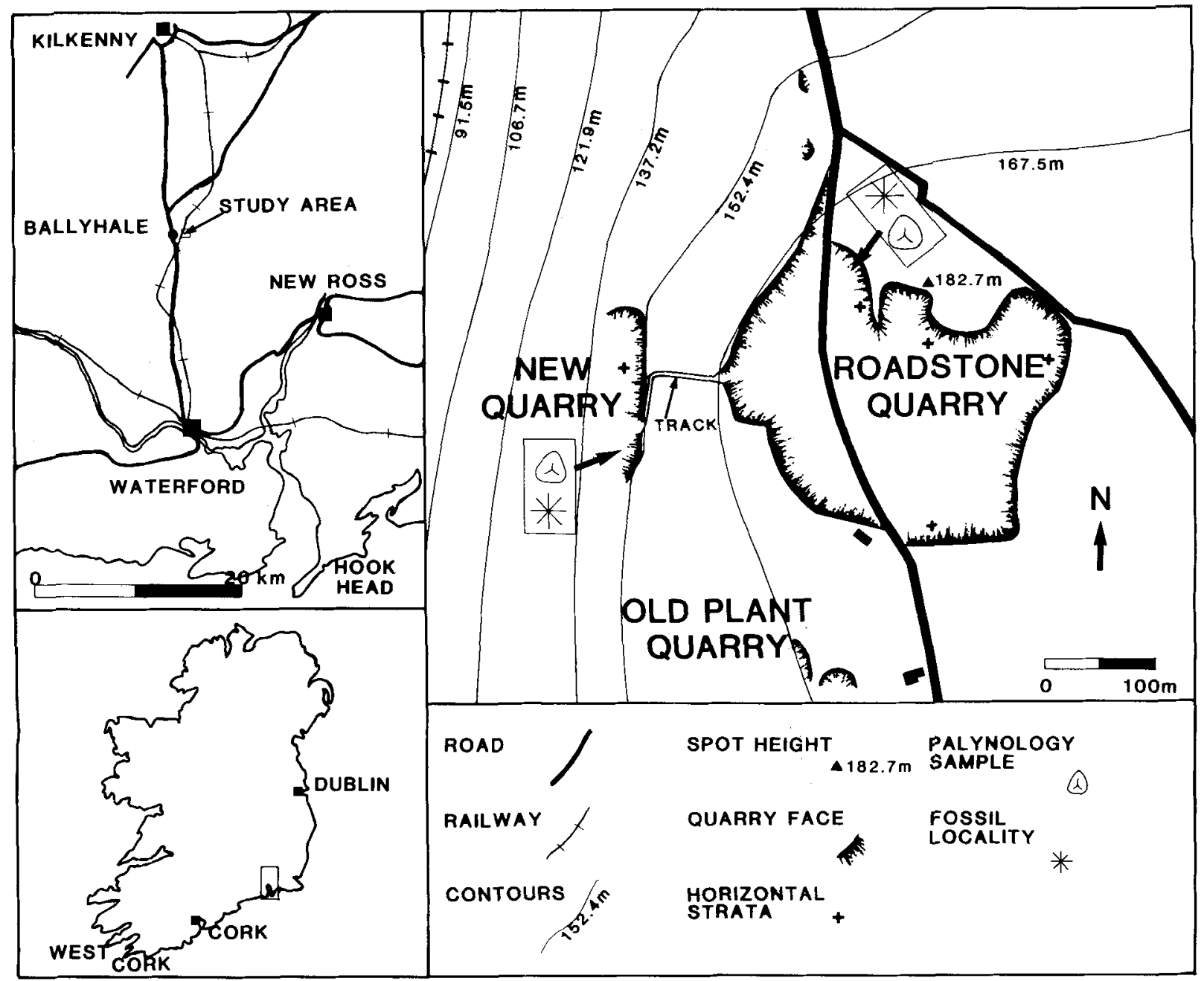

Fig. 1. Location map showing Kiltorcan Hill in County Kilkenny, Ireland, and the relationship between the sampled horizons.

described the discovery of seed Spermolithus devonicus during the re-excavation; This seed is important in the understanding of early gymnosperm evolution.

Clayton et al (1977) examined three palynological assemblages from the Kiltorcan Formation elsewhere in County Kilkenny. In this paper John Colthurst concluded that the sampled horizons were 40 and $50 \mathrm{~m}$ above the highest exposed levels on Kiltorcan Hill. Clayton et al (1977) suggest that the samples come from Carboniferous strata with an absence of Retispora lepidophyta correlating with the VI Miospore Biozone; Moreover, one of the higher samples contains Spelaeotriletes balteaus (Playford) Higgs, which suggests to the present author that the higher assemblage belongs to the higher BP Miospore Biozone of Higgs et al (1988) (Fig.3).

\section{EXPOSURE DESCRIPTION AND SAMPLED HORIZONS}

The Kiltorcan Formation is the highest division of the Old Red Sandstone facies (O.R.S.) in S. E. Ireland. The sediments of the Kiltorcan Formation exposed on Kiltorcan Hill consist mainly of siltstone and fine sandstone with laterally ex tensive coarse sandstone bodies occurring at two horizons. Fine grained arenaceous rocks show both vertical and lateral gradation between red and green colouration. Plant material is found in most of the green coloured sediment; there are, however, a number of horizons where plant material is especially common. These are: (1), at the base of the succession in the New Quarry, (2), the Old Plant Quarry and (3), in the northern part of the Roadstone Quarry. The Plant Quarry horizon contained both Archaeopteris hibernica and Cyclostigma kiltorkense whilst only C. kiltorkense is present at the New Quarry horizon. The floral assemblage collected from the Roadstone Quarry includes Lepidodendropsis spp. aff. L. hirmeri, cf. Rhacophyton spp. and the alga Bythotrephis spp. (pers. comm. W. S. Lacey 1989). Preservation in the Roadstone and Old Plant Quarries is by chloritisation whilst the New Quarry horizon shows coalified preservation. Palynology samples were collected from the New Quarry plant bed (sample 88/1) which is estimated to be some $20 \mathrm{~m}$ 
below the floor of the Old Plant Quarry, and from the Roadstone Quarry (sample CQl) an estimated 4 or $5 \mathrm{~m}$ above the topmost strata in the Old Plant Quarry.

\section{PREPARATION TECHNIQUES}

Numerous attempts were made by the author to extract a productive palynological sample from the plant beds in the Roadstone Quarry. Best results were obtained by collecting large amounts of thinly laminated dark grey mudstone found within green siltstone. These were then crushed and chemically broken down by hydroflouric acid. The resulting residue was then subjected to prolonged boiling in hydrochloric acid to remove the large amounts of flourides present. The organic residue obtained was small but contained a diverse and well preserved palynoflora. Samples from Kiltorcan New Quarry only required standard palynological techniques to produce a very rich residue. The palynological assemblages studied from both samples display lower levels of organic maturity than samples observed from similar horizons in the Kiltorcan Formation elsewhere in Southern Ireland. Thermal alteration index (TAI) values (Staplin 1982) in the order of 3, with a spore colour of dark yellow to orange brown (of Pearson 1984) were noted in unoxidised material. Oxidation times with Schulze Solution were limited to 1 hour for the New Quarry and 30 minutes for the Roadstone Quarry samples. Permanent scatter mounts were made using Cellusize as a dispersing agent and Elvacite as a cold mounting medium. These slides are housed in the Micropalaeontological collection of the Department of Geology, U.C.C.

\section{PALYNOLOGY RESULTS}

The palynological slides produced were carefully scanned for important stratigraphic forms and new species, systematic counts of 500 specimens were made for both samples. Undescribed species will be examined in a later paper. The preliminary results are shown below. The range of each species within the Miospore Biozones of the Tournaisian of Ireland is given after Higgs et al 1988. See Fig. 3 for Miospore Biozones.

SAMPLE 88/1.

LOCATION Kiltorcan New Quarry southern end.

HORIZON $20 \mathrm{~m}$ below Old Plant Quarry.

LITHOLOGY Grey Siltstone.

ASSOCIATED PLANTS $C$. kiltorkense, stems up to $7 \mathrm{cms}$ wide and $14 \mathrm{cms}$ length. Rootlets in bed below.

\section{NEW QUARRY SAMPLE ASSEMBLAGE LIST}

Apiculiretusispora fructicosa Higgs

Auroraspora macra Sullivan

Auroraspora solisortus Hoffmeister Staplin \& Malloy

Dictyotriletes trivialis Naumova in litt. Kedo

Corbulispora cancellata (Waltz)

Bharadwaj \& Venkatachala

Diducites mucronatus (Kedo) emend Van Veen

Diducites plicabilis VanVeen

Diducites versabilis (Kedo) emend Van Veen

Endoculeospora gradzinskii Turnau

LL- VI

LL- LN

LL- LN

LE- CM
Grandispora echinata Hacquebard

Grandispora cf. echinata Hacquebard

LL- CM

Hymenozonotriletes explanatus (Luber) Kedo

LL- VI

Plicatispora scolecophora (Neves \& Ioannides) Higgs, Clayton \& Keegen

Punctatisporites irrasus Hacquebard

Pustulatisporites cf. dolbii Higgs, Clayton \& Keegan

Raistrickia cf. macrura (Luber) Dolby \& Neves

Raistrickia variabilis Dolby \& Neves

Retispora lepidophyta (Kedo) Playford

Retispora macroreticulata (Kedo) Byvscheva

Retusotriletes planus Dolby \& Neves

Rugospora flexuosa (Jushko) Streel

Spelaeotriletes crenulatus (Playford)

Higgs, Clayton \& Keegen

Velamisporites caperatus (Higgs)

Higgs, Clayton \& Keegen

LL- PC

LL- CM

LL- CM

LL- PC

LL- PC

LL- CM

LL- LN

LL- LE

LL- PC

LL- LN

LL- CM

LL- LN

\section{QUANTITATIVE ANALYSIS}

$\%$ of total based on count of five hundred specimens.

$\begin{array}{ll}\text { Retispora lepidophyta } & =66.3 \% \\ \text { Diducites } & =1.9 \% \\ \text { Rugospora flexuosa } & =4.3 \% \\ \text { Hymenozonotriletes explanatus } & =1.6 \% \\ \text { Others } & =25.9 \%\end{array}$

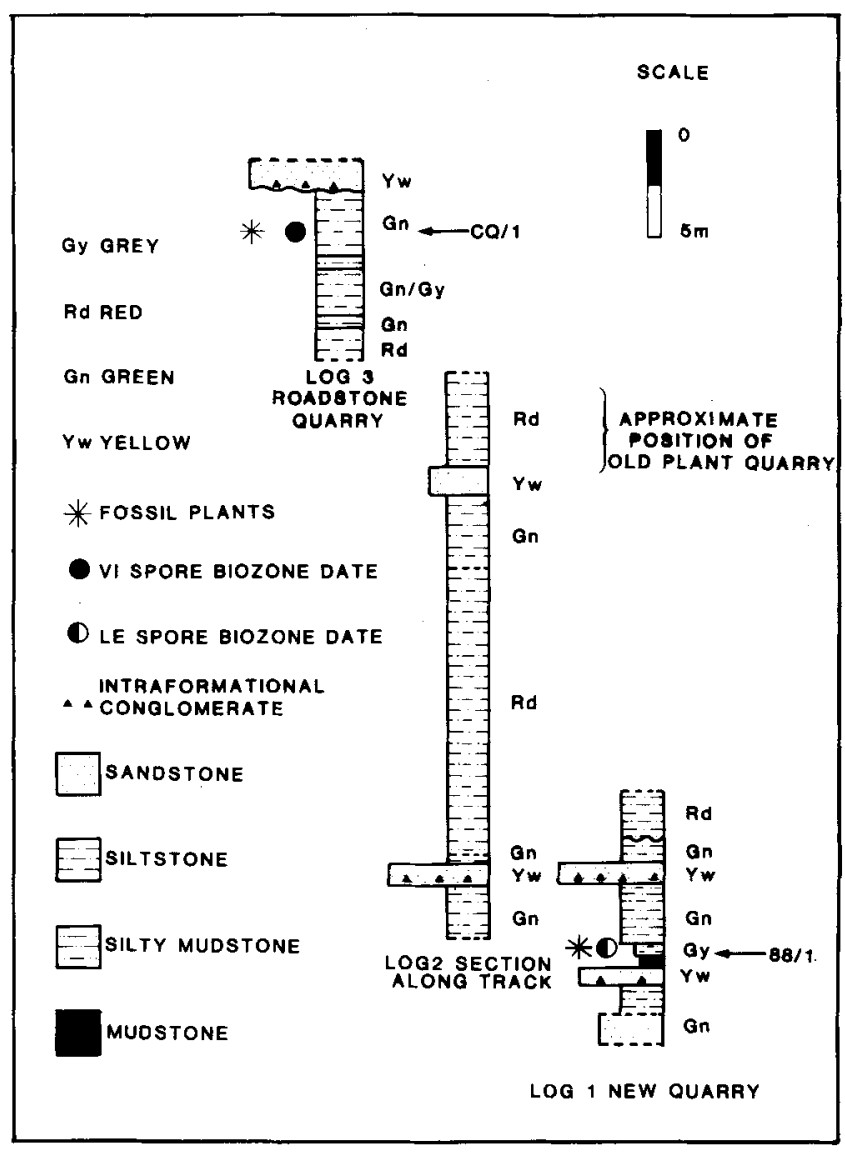

Fig. 2. Graphic logs showing the succession on Kiltorcan Hill and the location of productive palynology samples. 


\section{SAMPLE CQ1}

LOCATION Kiltorcan Roadstone Quarry, northern end.

HORIZON $5 \mathrm{~m}$ above Old Plant Quarry.

LITHOLOGY Dark grey fine siltstone and mudstone laminae in green siltstone and fine sandstone unit

ASSOCIATED PLANTS Lepidodendropsis spp., and ?Rhacophyton. Mostly Lepidodendropsis spp. stems up to 2 cms wide and $15 \mathrm{cms}$ long; some current alignment.

\section{ROADSTONE QUARRY SAMPLE ASSEMBLAGE} LIST

Apiculiretusispora fructicosa Higgs

Auroraspora asperella (Kedo) Van der Zwan

Auroraspora corporiga Higgs, Clayton \& Keegen

Bascaudaspora collicula (Playford)

Higgs, Clayton \& Keegan

Convolutispora vermiformis Hughes \& Playford

Cymbosporites minutus (Kedo)

Avchimovitch \& Streel

Dictyotriletes trivialis Naumova in litt. Kedo

Grandispora spp.

Kraeuselisporites fasciatus Higgs

Knoxisporites literatus Waltz (Playford)

Knoxisporites triangularis Higgs, Clayton \& Keegen VI- CM

Leiotriletes trivialis Naumova

Plicatispora quasilabrata (Neves \&

Ioannides) Higgs, Clayton \& Keegen

Retusotriletes incohatus Sullivan

Retusotriletes triangulatus (Streel) Streel

Spelaeotriletes obtusus Higgs

Spelaeotriletes resolutus Higgs

Verrucosisporites nitidus (Naumova) Playford

Vallatisporites vallatus Hacquebard

Vallatisporites verrucosus Hacquebard

QUANTITATIVE ANALYSIS

LL- CM

LN- CM

VI- PC

LL- PC

LL- CM

LL- PC

LE- CM

LL- PC

LL- PC

LL- CM

LL- VI

LL- CM

LL- CM

LL- PC

VI- BP

VI- PC

LN- CM

VI- CM

LL- CM

$\%$ of total based on count of five hundred specimens.

Spelaeotriletes spp. $\quad=5.9 \%$

Verrucosisporites nitidus $\quad=2.6 \%$

Vallatisporites vallatus $\quad=0.8 \%$

Others, mostly acamerate

weakly ornamented forms

$=90.7 \%$

\section{STRATIGRAPHIC IMPLICATIONS.}

Higgs et al (1988) published a palynostratigraphical zonation for the Tournaisian rocks of Ireland (Fig3). In this zonation the LL, LE and LN Miospore biozones belong to the "Strunian" (Upper Devonian) part of the Tournaisian. The VI Spore Biozone and higher Biozones belong to the lowermost Carboniferous The assemblages recorded can be correlated with this miospore zonation scheme. The lowest sample studied, 88/1, contains abundant amounts of Retispora lepidophyta which together with the presence of other biostratigraphically important forms such as Rugospora flexuosa,Diducites plicabilis and Diducites versabilis indicate a Devonian age for this sample. The presence of Hymenozonotriletes explanatus and the absence of Verrucosisporites nitidus and Vallatisporites verrucosus indicate the assemblage belongs to the LE Miospore Biozone suggesting a Strunian early Tnlb age.

In contrast, the palynological assemblage extracted from the plant beds in the Roadstone Quarry co $^{-}$gains no Retispora lepidophyta, Rugospora flexuosa or Diducites versabilis.

Moreover, Verrucosisporites nitidus is present and Spelaeotriletes obtusus and Spelaeotriletes resolutus were found in high percentages. These combined factors indicate the assemblage belongs to the VI Biozone, whilst the the absence of Kraeuselisporites hibericus and Umbonatisporites distinctus indicates the age to be lowermost Courceyan, late Tnlb.

It therefore appears that the Devonian/Carboniferous Boundary occurs within the $25 \mathrm{~m}$ between the two study horizons.

\section{PALAEOENVIRONMENTAL IMPLICATIONS}

Van der Zwan and Van Veen (1978) and Van Veen (1981) working on sections of uppermost O.R.S in West Cork and Hook Head (Fig. 1) made palaeogeographical reconstructions from the distribution of selected miospore taxa. Van Veen (1982) concluded that Diducites was related to an alluvial plain environment whilst Retispora lepidophyta was related to a coastal area environment in LN and LE Biozone times. He does, however, go on to state that "the regional and interregional implications of such environmentally controlled dominances can only be estimated when comparable data from other sections are available"

Comparison of Van Veen's model with data from the present study is unfavorable. Palaeoenvironmental conditions for the New Quarry strata are interpretated as humid alluvial plain, however, Retispora lepidophyta is found in great amounts comprising $66.3 \%$ of the total palynological assemblage, whilst Diducites only makes up $1.9 \%$ of the same. Van Veen's (op. cit.) model would suggest the high percentage of R.lepidophyta was due to deposition on a coastal plain environment, this is not so in the case in hand. However, the presence of R.lepidophyta in large percentages does appear to be related to a palaeoenvironmental factor. Sedimentological analysis of the Kiltorcan Formation at this locality suggest that the sediments were laid down on a humid, wet floodplain. These conditions may have been much more water saturated than the conditions under which the O.R.S. alluvial plain sediments elsewhere in Southern Ireland were deposited. Moreover, humidity and water saturation levels in the coastal plain O.R.S. environments Van Veen (op.cit.) studied may have been much closer to those of the Kiltorcan Formation. Thus the high percentages of R.lepidophyta in the uppermost O.R.S. could represent conditions of high humidity and water saturation at the time of deposition. The relative percentages of Diducites and R.lepidophyta in late Devonian palynological assemblages may therefore prove to be an indicator of humidity and water saturation of environment rather than a palaeogeographical indicator.

\section{BIOSTRATIGRAPHICAL IMPORTANCE OF THE MEGAFLORA}

In terms of dating the macroplant beds the palynological 


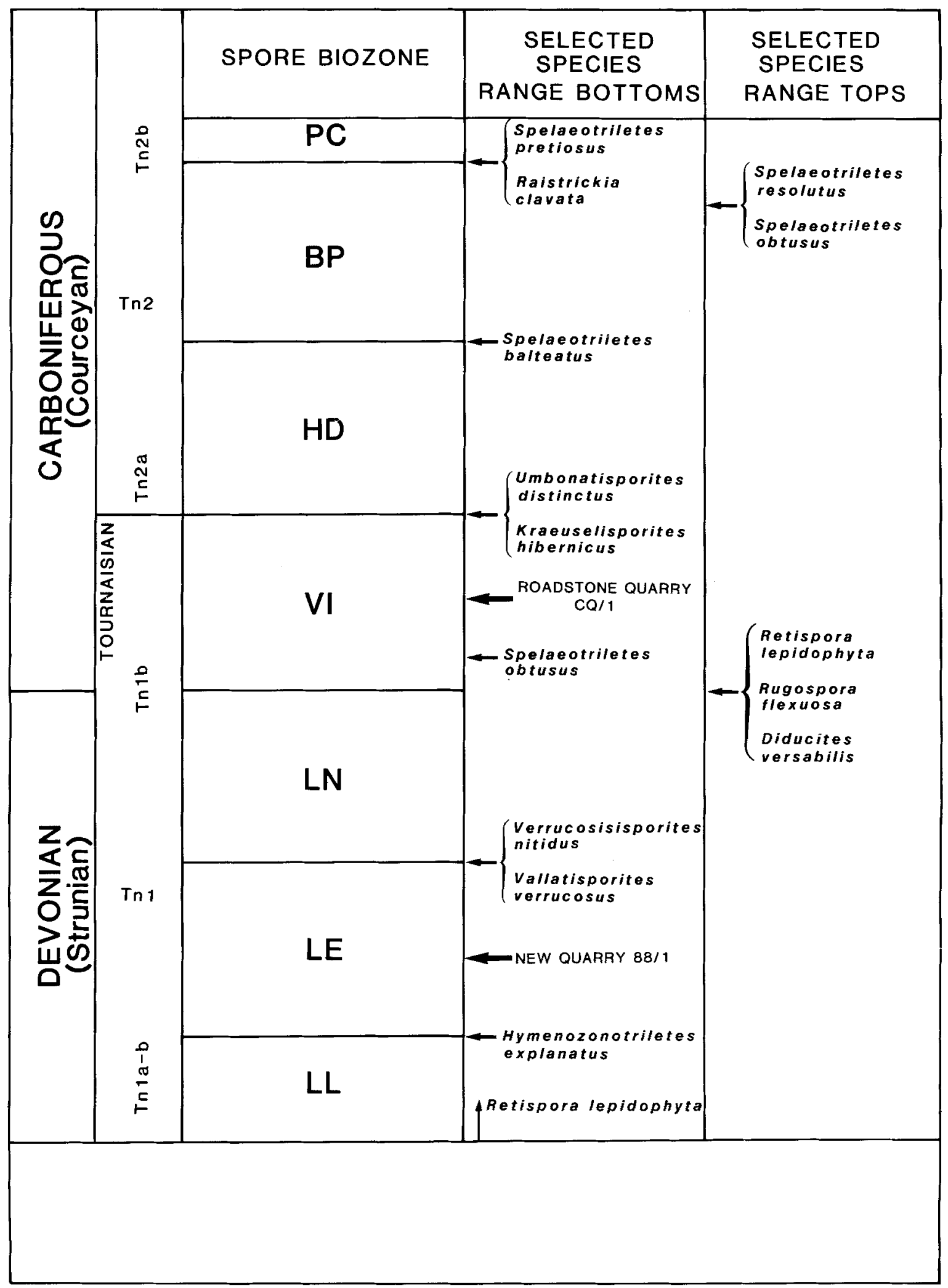

Fig. 3. Miospore biozones for the Tournaisian of Ireland (after Higgs et al 1988). With stratigraphic positions of dated horizons in present study. 
results indicate that the Lepidodendropsis spp. and the cf. Rhacophyton spp. flora is restricted to Carboniferous strata, whilst the only dated horizons with Cyclostigma kiltorkense are Devonian. However, the range top of Cyclostigma kiltorkense is problematical, the horizons which contain $C$. kiltorkense are at least $20 \mathrm{~m}$ apart and only the lower horizon is dated as belonging to the LE Miospore Biozone. In contrast the plant assemblage in the Roadstone Quarry some $5 \mathrm{~m}$ above the upper occurrence of $\mathrm{C}$. kiltorkense yielded a lowermost Carboniferous (VI Spore Biozone) age. The exact level of the Devonian\Carboniferous Boundary therefore remains unknown. The abrupt change in floral assemblage between the Old Plant Quarry and the Roadstone Quarry appears to be significant, the lower flora of the Old Plant Quarry may be Devonian whilst the upper plant bed in the Roadstone Quarry is definitely lowermost Carboniferous. I would therefore tentatively suggest that Cyclostigma kiltorkense and Archaeopteris hibernica are restricted to the Upper Devonian at Kiltorcan Hill with their probable range tops in the LE or the LN Miospore Biozones. No unequivocal evidence is available due to the lack of suitable sample horizons in the Old Plant Quarry, but it may be the case that the Devonian\Carboniferous Boundary occurs within the red silt between the Old Plant Quarry and the Roadstone Quarry.

Fairon-Demaret (1986) made a stratigraphical review of uppermost Devonian megafloras. In that paper discussion as to the time-restricted distribution of Cyclostigma kiltorkense was given. Occurrences of $C$. kiltorkense outside Southern Ireland are rare; Fairon-Demaret (op. cit) discusses floral assemblages including $C$. kiltorkense from Bear Island and Siberia (Schweitzer 1969) and South and Southeastern China (Li Xingxue et al 1984, and Huang Da-Xin 1978). Kaiser (1970) examined palynological assemblages from the $C$. kiltorkense bearing sequence at Bear Island, the present author's interpretation of Kaiser's (1970) assemblage list suggests the flora at Bear Island is preserved in Devonian strata from the LE Miospore Biozone. Palynological dates from these sections, therefore, suggest that $C$. kiltorkense could be restricted to the Strunian. Fairon-Demaret (op. cit) suggested that the stratigraphically restricted record of $C$. kiltorkense is indicative of it's index value for an upper subzone in Bank's floral assemblage VII (Banks 1980). However, Fairon-Demaret (op. cit) also notes that precise dating of the Kiltorcan Hill horizon is needed before absolute conclusions are to be drawn.

The palynological evidence from the present study adds support to the suggestion that Cyclostigma kiltorkense on Kiltorcan Hill could possibly be restricted to the Strunian. Fairon-Demaret (op. cit) also notes that the range top of the genus Archaeopteris is unknown "with it's persistance in the

Explanation of Plate 1

All Magnifications x 420

FIGS. 1-11 UPPER DEVONIAN (STRUNIAN) ASSEMBLAGE

$\begin{array}{ll}\text { Fig. 1. } & \text { Retispora lepidophyta } \\ \text { Fig. 5. } & \text { Retispora lepidophyta Unoxidised } \\ \text { Fig. 6 } & \text { Retispora lepidophyta } \\ \text { Fig. 2 } & \text { Vallatisporites pussillites } \\ \text { Fig. 3. } & \text { Auroraspora solisortus } \\ \text { Fig. 4. } & \text { Rugospora flexuosa } \\ \text { Fig. } 7 & \text { Retispora macroreticulata } \\ \text { Figs. 8 \& 10 } & \text { Hymenzonotriletes explanatus } \\ \text { Fig. } 8 & \text { Hymenzonotriletes explanatus } \\ \text { Fig. 10 } & \text { Hymenzonotriletes explanatus } \\ \text { Fig. } 9 . & \text { Diducites polijessicus } \\ \text { Fig. 11 } & \text { Diducites versabilis }\end{array}$

$\begin{array}{lr}88 / 1-1 & \mathrm{~V} 37 \\ 88 / 1-0 & \mathrm{U} 30 / 4 \\ 88 / 1-3 & \mathrm{E} 55 \\ 88 / 1-\mathrm{A} & \mathrm{U} 24 / 4 \\ 88 / 1-\mathrm{A} & \mathrm{W} 12 / 2 \\ 88 / 1-3 & \mathrm{~B} 44 / 3 \\ 88 / 1-\mathrm{A} & \mathrm{L} 9 / 4 \\ & \\ 88 / 1-\mathrm{A} & \mathrm{W} 24 / 4 \\ 88 / 1-3 & \mathrm{C} 37 / 4 \\ 88 / 1-\mathrm{A} & \mathrm{W} 24 / 3 \\ 88 / 1-3 & \mathrm{C} 37 / 4\end{array}$

FIGS. 12-23 LOWER CARBONIFEROUS ASSEMBLAGE

$\begin{array}{lllr}\text { Fig. 12 } & \text { Verrucosisporites nitidus } & \text { CQ1-A } & \text { V26 } \\ \text { Fig. 13 } & \text { Verrucosisporites nitidus } & \text { CQ1-E } & \text { E13 } \\ \text { Fig. 14 } & \text { Cymbosporites minutus } & \text { CQ1-B } & \text { E17/1 } \\ \text { Fig. 15 } & \text { Spore type A } & \text { CQ1-G } & \text { R11 } \\ \text { Fig. 16 } & \text { Retusotriletes incohatus } & \text { CQ1-B } & \text { J41/2 } \\ \text { Fig. 17 } & \text { Auroraspora corporiga } & \text { CQ1-G } & 039 / 4 \\ \text { Fig. 18 } & \text { Spelaeotriletes resolutus } & \text { CQ1-B } & \mathrm{N} 27 \\ \text { Fig. 19 } & \text { Convolutispora vermiformis } & \text { CQ1-B } & \text { L24/4 } \\ \text { Fig. 20 } & \text { Spelaeotriletes obtusus } & \text { CQ1-A } & \text { S12/4 } \\ \text { Fig. 21 } & \text { Bascaudaspora collicula } & \text { CQ1-E } & \mathrm{N} 20 / 1 \\ \text { Fig. 22 } & \text { Vallatisporites vallatus } & \text { CQ1-E } & \mathrm{H} 3 / 2 \\ \text { Fig. 23 } & \text { Vallatisporites vallatus } & \text { CQ1-G } & \text { P34 }\end{array}$



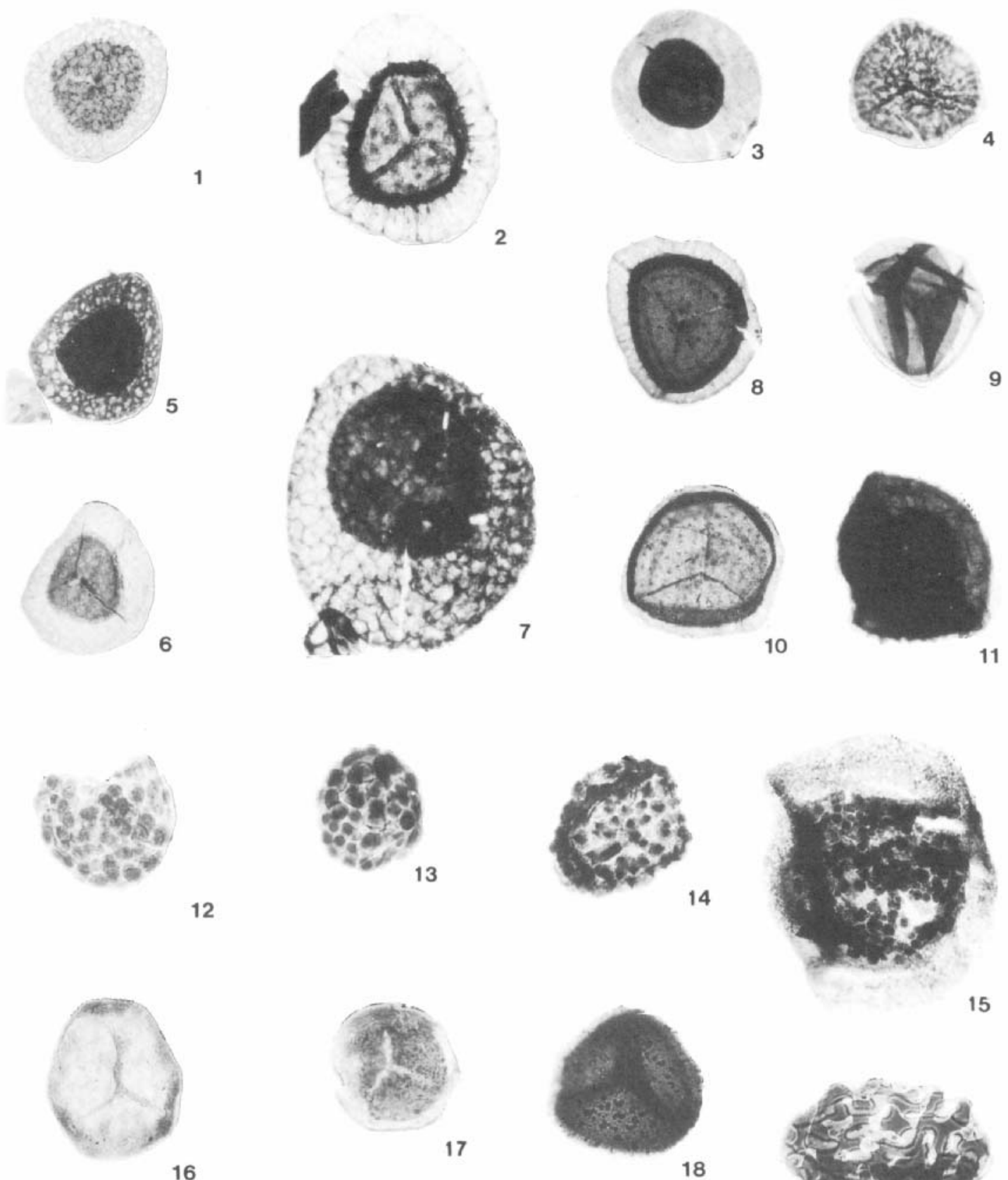

15

16
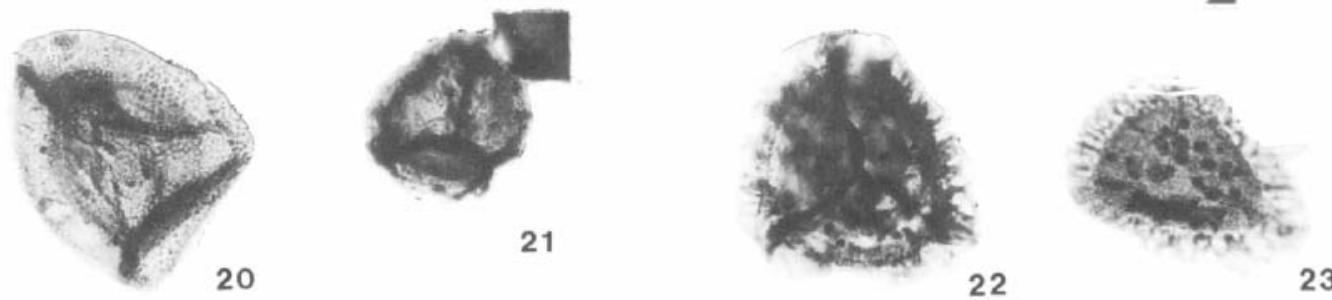
Lower Carboniferous still depending on precise dating of critical localities as in the New Albany Shale and in the Kiltorcan Formation". From the present study it appears that the occurrence of Archaeopteris hibernica on Kiltorcan Hill could also be restricted to the Devonian.

Chaloner et al. (1977) described a seed Spermolithus devonicus from the Kiltorcan Old Quarry. This seed was suggested to be the first Devonian platyspermic seed. It should be noted that a Devonian age for this seed is not precluded.

\section{ACKNOWLEDGEMENTS}

This research was carried out under a Departmental Studentship from the Department of Geology, University College Cork. Thanks are due to Dr. Ken Higgs (U.C.C.) for his comments on the manuscript, Professor Lacey (Bangor University) for information on the megaflora and Professor P. M. Brück (U.C.C.) for the use of departmental facilities. I would also like to thank Ms. Ger O'Connor (U.C.C.) for assistance in collecting samples, and Dr. T. M. Sweetman and Mr. R.G. W. Heselden (U.C.C.) for help and comments on the drafting of diagrams. Thanks are due to an anonymous referee for comments on the original manuscript.

\section{Manuscript received August 1989 \\ Revised manuscript accepted January 1990}

\section{REFERENCES}

Baily, W. H., 1861, Palaeontological notes in Jukes, J. B., DuNoyer, G. V., Baily, W. H., and Kinahan, G. H., Explanations to accompany sheets 147 and 157 of the maps of the Geological Survey of Ireland, illustrating the parts of Co. Kilkenny, Carlow and Wexford. Mem. Geol. Surv. Ire.

Baily, W. H., 1869, On fossils obtained at Kiltorkan Quarry, Co. Kilkenny. Br. Assoc. Adv. Sci. Rep. 72-75.

Banks, H.P., 1980, Floral assemblages in the Siluro-Devonian. In Biostratigraphy of Fossil Plants, Dilcher. D. L. and Taylon, T. N. (eds), Dowden, Hutchinson and Ross Inc., 24pp.

Chaloner, W. G., 1968, The cone of Cyclostigma kiltorkense Haughton, from the Upper Devonian of Ireland., J. Linn. Soc (Bot.), 61, 25-36.

Chaloner, W.G., Hill, A.J. and Lacey, W.S., 1977, First Devonian Platyspermic seed and its implications in gymnosperm evolution. Nature, 265, 233-235.

Clayton, G., Colthurst, J.R.J., Higgs, K., Jones, G.LL., and Keegan, J.B., 1977, Tournaisian miospores and conodonts from County Kilkenny., Geol. Surv. Ire. Bull., 2, 99-106.

Clayton, G., Graham, J.R., Higgs, K., Holland, C.H., and Naylor, D., 1980, Devonian Rocks in Ireland; A review. J Earth Sci. R. Dubl. Soc., 2, 161-183.

Colthurst, J.R.J., 1978, Old Red Sandstone Rocks surrounding the Slievenamon inlier, Counties Tipperary and Kilkenny. $J$. Earth Sci, R. Dubl. Soc., 1, 77-103.

Fairon-Demaret, M., 1986, Some Uppermost Devonian Megafloras: a Stratigraphical Review. Ann. Soc. Geol. Belg., 109, 4348

Forbes, E., 1853, On the fossils of the Yellow Sandstone of the South of Ireland. Br. Assoc. Adv. Sci., Rep. (22nd meeting), 22, 43.
Griffith, R., and Brongniart, A., 1857, On the fossil plants which have been discovered in the rocks at the base of the Carboniferous system in Ireland. J. Geol. Soc. Dubl., 7, 287293.

Griffith, R., and Brongniart, A., 1858, On the fossil plants which have been discovered in the rocks at the base of the Carboniferous system in Ireland. J. Roy. Dubl. Soc., 1, 313.

Haughton, S., 1855, On the evidence afforded by fossil plants, as to the boundary line between the Devonian and Carboniferous rocks. J. Geol. Soc. Dubl., 6, 227-241.

Haughton, S., 1859, On Cyclostigma at Ballyhale, Co. Kilkenny. Nat. Hist. Review. 7, 209.

Higgs, K., Clayton, G., and Keegan, J.B., 1988, Stratigraphic and Systematic Palynology of the Tournaisian Rocks of Ireland., Geol. Surv. Ire. Spec. Pap., 7, 93 pp.

Holland, C.H., 1981, Devonian. in A Geology of Ireland. Holland, C.H. (Ed.). Scottish Academic Press, Edinburgh.

Huang Da-Xin, 1978, On the subdivision of the "Xuefengshan Sandstone" and a supplement to the concept of the "Shaodong Member". Prof. Pap. Symposium on the Devonian System of South China. Geological Publishing House, Beijing.

Johnson, T., 1913 b, On Bothrodendron (Cyclostigma) kiltorkense, Haughton. Scient. Proc. R. Dubl. Soc., 13, 500525.

Kaiser, H., 1970, Die OberDevon- Flora der Bäreninsel. 3. Mikroflora des Hohoren OberDevons und des UnterKarbons.Palaeontographica Abt. B, 129, 71-124.

Li Xingxue, Cai Chongyang and Ouyang Shu., 1984, Recent advances in the Study of the Wutong Formation of the Lower Yangtze Valley. Bull. Chinese Acad. Geol. Sci., 9, 119-133.

Pearson, D. L., 1984, Pollen/spore color "standard", version 2. Phillips Petroleum Co.

Schweitzer, H.J., 1969, Die OberDevon- Flora der Bäreninsel. 2. Lycopodinae. Palaeontographica Abt. B, 126, 101-137.

Staplin, F.L., 1982, Determination of thermal alternation from colour of exinite (pollen, spores). In Staplin, F.L., et al, How to Assess Maturation and Paleotempertures, Soc. Econ. Palaeo. Mineral. Short Course No. 7, 7-12.

Van der Zwan, C.J. and Van Veen, P.M., 1978, The Devonian - Carboniferous sequence in Southern Ireland; Integration of palaeogeography and palynology., Palinologia, 1, 469-479.

Van Veen, P.M., 1981, Aspects of Late Devonian and Early Carboniferous Palynology in Southern Ireland. V., The change in composition of palynological assemblages at the Devonian Carboniferous boundary., Rev. Palaeobot. Palynol., 34, 67-97. 